\title{
Internet media and the public sphere: The 2007 Australian e-electioneering experience
}

\author{
Jim Macnamara \\ University of Technology Sydney
}

\begin{abstract}
Internet media have come under increasing examination since the early 1990s within a number of theoretical frameworks including their use and potential influence in the public sphere of political discourse. Increasing use of internet media was identified in the 2000 and 2004 US presidential elections, the latter being described as "a critical turning point". However, the development of what some call 'new media' or 'social media' based on web 2.0 internet technology have overtaken many findings of previous research. Some of the most popular web 2.0-based media currently in use were developed post-2004. These technological changes, coinciding with declining television viewing and newspaper readership, suggest that new forms of internet media need ongoing critical review. This paper analyses findings from a study of internet media use in the 2007 Australian federal election and explores their implications in relation to the public sphere.
\end{abstract}

\section{Introduction}

Major change is underway in how public communication in political election campaigns is conducted in modern democratic societies. In 2007 and 2008 during the US primaries leading up to the 2008 presidential election, it was noted and extensively reported that candidates, political parties and political activists used a range of interactive web $2.0^{1}$ media (Media Monitors, 2008). Hillary Clinton announced her candidacy for the US presidency on YouTube. Videos of political candidates posted on YouTube and other social media sites such as MySpace have been widely accessed. For example, a privately recorded song 'I got a crush on Obama' sung by a young woman calling herself 'Obama Girl' was reportedly viewed by 20 million people in just a few months after it was posted on 14 June 2007 (Young voters caught hook, line and sinker, 2007).

Political electioneering using web 2.0 internet media is also emerging in Australia and other countries. In July 2007, in approaching the federal election, the then Prime Minister John Howard posted a video discussing climate change policy on YouTube which attracted widespread comment online and in mainstream media - albeit much of it uncomplimentary. For instance, The Age reported on 25 October 2008: “John Howard's foray into YouTube was a complete flop, provoking hundreds of 'mashups' and satirical responses attacking the PM and his policies” (Media Monitors, 2008: 4). The then federal Opposition Leader, Mr Rudd, also produced online videos which attracted substantial audiences and provoked widespread debate (Australian Centre for Public Communication, 2008).

The 2007 Australian federal election was labelled "the YouTube election" (The YouTube election, 2007) by mainstream media, and claims were made for a reinvigoration of the public sphere. The Daily Telegraph quoted the then Opposition Spokesperson on the Environment and the Arts and now Minister for The Environment, Heritage and the Arts, Peter Garrett, saying "the internet has made politicians more accountable and more accessible” (Poll puts it all online, 2007). 
Use of internet media for public communication has come under increasing examination since the early 1990s, with two broad schools of thought emerging on the social and political implications. On one hand, optimists enthuse about the potential of internet media to give people greater access to information and create a reinvigorated public sphere (Bentivegna, 2002; Corner, 2007; Jenkins, 2006; Rheingold, 1993). Corner (2007: 223) notes that many commentators see the development of the internet, and particularly web 2.0 type interactive communication, allowing "a bypassing of the degraded central systems of mediation in favour of a more independent, varied and critical range of resources for political knowledge". On the other hand, pessimistic perspectives warn of a breakdown in social connectedness and a "loss of social capital” (Putnam, 1995, 2000; Shapiro and Leone, 1999; Wellman, 2000) caused by the depersonalisation inherent in mediated internet communication and time spent with media rather than human interaction, termed the displacement hypothesis (Sparks, 2006: 72-3). Also, critics and sceptics point to a "digital divide" between those with access to new digital media and those with restricted or no access because of financial or other limitations (Gandy, 2002; Hoffman and Novak, 1998; Novak and Hoffman, 1998).

Use of the internet for political communication has been studied by many scholars and organisations including Bentivegna (2002); Fallows (2000); Hill and Hughes (1998); Jones (1995, 1998); Livingstone (1999); McChesney (1996, 2000); Pool (1983); Schneider (1996, 1997) and the Markle Foundation (1997), to name but a few. However, the evolution of web 2.0 internet applications, rapidly expanding broadband, declining cost of personal computers and internet access, development of intelligent search engines which have replaced 'surfing, ${ }^{2}$ and make finding information on the internet faster and easier, and possibly increasing user familiarisation with internet use, have overtaken many findings of most pre-2000 research and even much research conducted in the early 2000s. Many of the media currently in use were 'invented' or began to achieve widespread use post-2004 (for example, YouTube was launched in February, 2005).

Rapid advances in technology, increasing use of the internet for political communication, and social change including declining newspaper readership and television viewing (Australian Media and Communications Authority, 2007; Roy Morgan, 2007) indicate that the social, political and media implications of internet media need ongoing critical review.

\section{Internet media use in the 2007 Australian federal election}

A study conducted by the Australian Centre for Public Communication at the University of Technology Sydney found that descriptions of the 2007 Australian federal election as the "YouTube election" and the "internet election" were greatly exaggerated. The study reported that, in the final week of the election, only 26 (11.5 per cent) of Australia's 226 Members of the House of Representatives and Senators had a MySpace site; just 15 (6.6 per cent) had a blog; only 13 (5.75 per cent) had posted videos on YouTube; just eight (3.5 per cent) had a Facebook site; and only seven (3.1 per cent) had a podcast. Almost 40 per cent of sitting parliamentarians did not have a personal web site (Australian Centre for Public Communication, 2008: 10). 


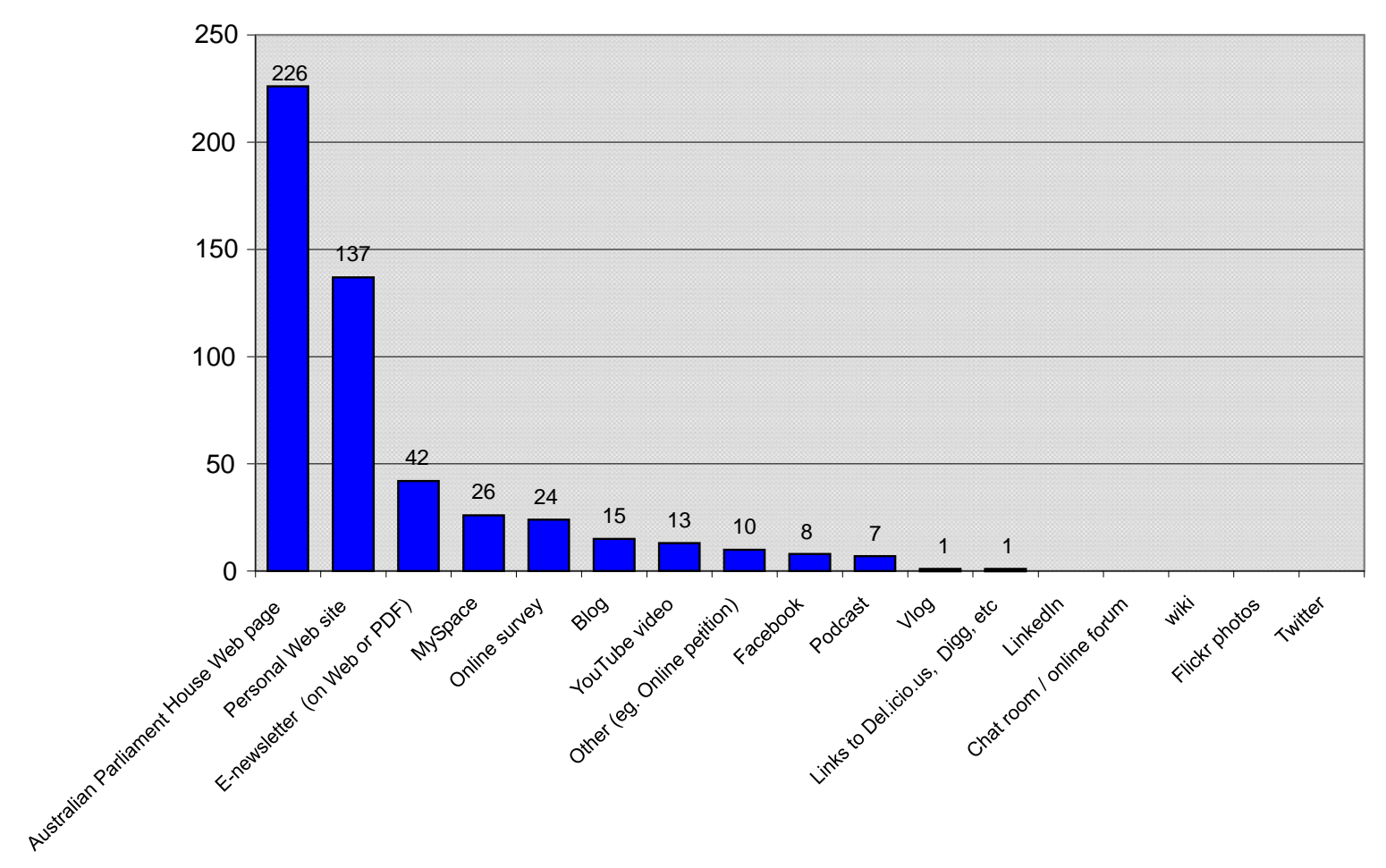

Figure 1. Types of internet media used by Australian federal politicians in the 2007 election.

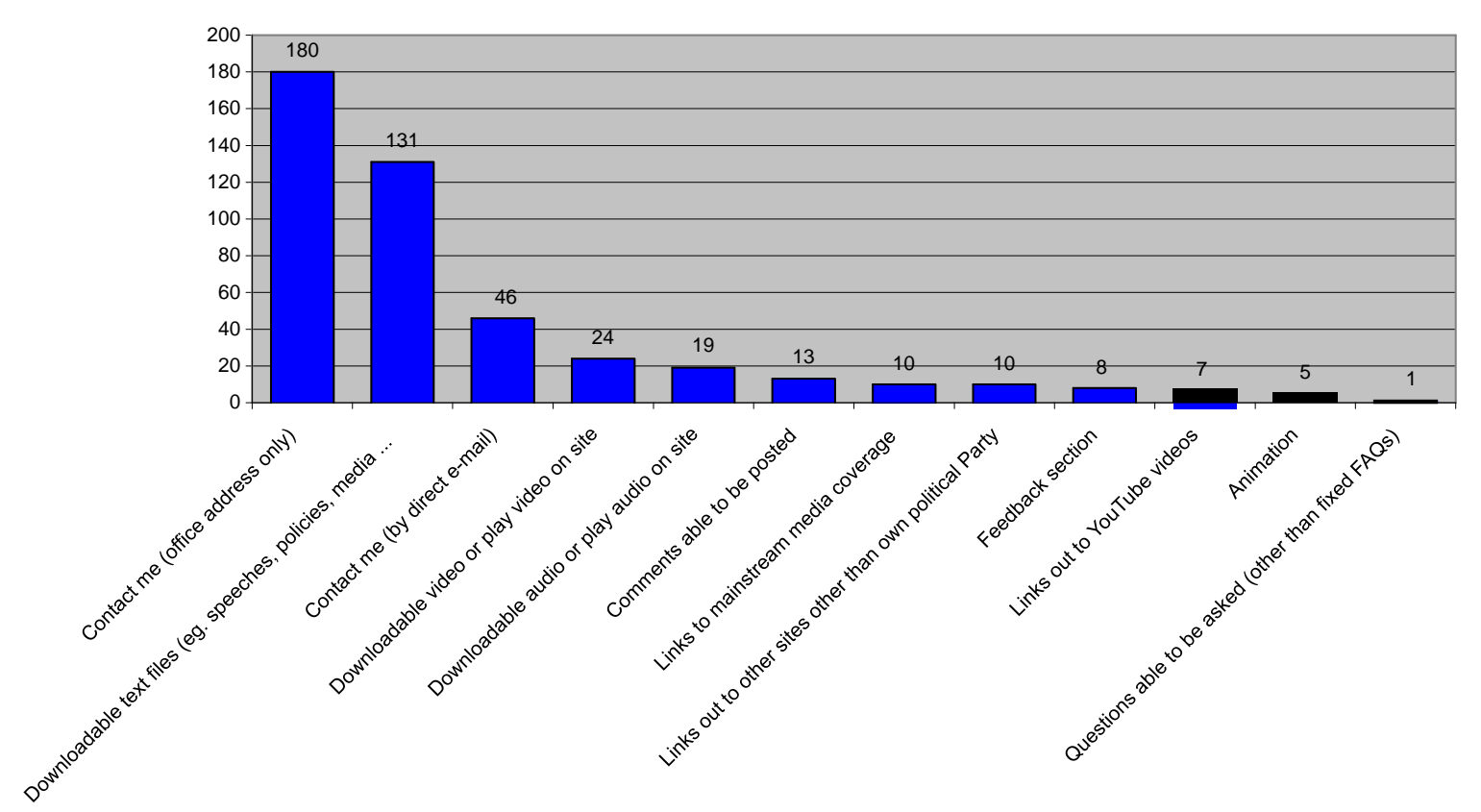

Figure 2. Interactive features on Australian federal politicians' internet sites during the 2007 election.

Also the study found that most internet communication used by politicians did not utilise the interactivity and 'conversation' features that distinguish web 2.0 media such as blogs, MySpace, Facebook and YouTube. Instead, the study found that 'comments' were often turned off or, when allowed, were almost always moderated by 'gatekeepers', resulting in dialogue being restricted almost exclusively to "fan mail". Only one Australian politician posted negative and critical comments from a member of the public. 
Content and text analysis also revealed that, despite the much-acclaimed success of the Australian Labor Party's Kevin07 web site and related MySpace sites and blogs, described as a "watershed" and as a "world first” by Labor campaign spokesperson, Penny Wong (A ringing endorsement, 2007), political parties primarily used the internet for one-way dissemination of information and restricted public access on their sites to supporters' comments. No negative or critical comments were found on any political party site.

However, the public sphere for political debate is receiving a boost online from political interest and activist groups and through citizen journalism and comment posted to what are termed social networking sites. Significant interaction and public engagement was found on sites such as Get Up (www.getup.org.au) which claimed more than 200,000 'members' during the election (more than some political parties); Senator On-Line (www.senatoronline.org.au) which stood political candidates in the election and claimed to be the first internet political party in the world; Election Tracker (www.electiontracker.net.au) funded by the not-for-profit youth media and arts group Vibewire to present a youth perspective on political issues; and You Decide (http://youdecide2007.org) which invited citizens to report on issues in their electorates. Also, a specialist Australian federal election site set up by Google (www.google.com.au/election2007) provided searchable information on political speeches and policies in an 'On the Record' section and a facility to check electoral names and boundaries in Google Maps.

In addition, the study reported that, despite some self-indulgent rants - for example, one blog was titled “Alex's rants, raves and thoughts' (Scholtzer, 2007) - a number of independent blogs contributed incisive analysis and commentary. For instance, several specialist blogs more accurately predicted the election result than mainstream media which focussed on reporting opinion polls.

Another type of web 2.0 user-generated media use highlighted by the study was a large number of spoofs and parodies and some malicious and obscene comments posted on open sites such as YouTube which often outnumbered official political communication. The study described interactive media as "a double-edged sword for political candidates and parties” as they can be damaging (Australian Centre for Public Communication, 2008: 10), particularly when online material is reproduced and widely distributed by mainstream media, a form of intermediation (Severin and Tankard 2001: 232) which is increasingly common.

The research raises many questions about the nature of the public sphere today, about what constitutes politics and political engagement, and about the media, which invite analysis and further research. Drawing on these findings, three key questions are explored in this paper in relation to the public sphere.

A key element of the Habermasian notion of a public sphere is that it has been envisioned as characterised by reasoned debate among equals, a realm of "rational-critical debate" (Habermas, 1989). While Habermas' original concept of the public sphere as taking place primarily through face to face communication has been replaced by a model in which media constitute a key discursive space for political debate (Garnham, 1992; Howley, 2007: 343, 358; Poster, 1997: 209), and a number of scholars propose that there are multiple overlapping publics, public spheres or "public sphericles" rather than a single public sphere (Fraser, 1992; Gitlin, 1998; Goode, 2005; Howley, 2007; Meadows, 2005; Warner, 2002: 53), the modernist rationalist notion has remained a core concept in liberal democracies. 
The Habermas-envisioned public sphere, even in its revised forms, has been criticised and seen as unrealised or unachievable by some scholars because of its "idealisation of public reason" (Curran, 2002: 45), because of unequal distribution of power that permeates societies (Foucault, 1980, 1998), and because of influences which limit access of individuals to this discursive space such as concentrated media ownership and control, editorial 'gatekeepers', and technological barriers such as lack of access to printing presses, broadcast spectrum, or the internet. McChesney (1996) argues that structural limitations have resulted in "a partial public sphere" at best. In addition to these critiques, Habermas and critical theorists of the Frankfurt School saw the rise of consumer culture promoted by mass media with their focus on commercialism and entertainment contributing to a degeneration of the public sphere as a site for deliberative democracy (Howley 2007: 343). A 1997 Markle Foundation review (cited in Bentivegna, 2006: 56) particularly criticised the internet as a site for the mediated public sphere commenting: "at worst, the internet produces a web of deceptive information, at best it offers a flow of decontextualised information that is hard to decipher and utilise". Further, Habermas (2006: 423) himself and others have expressed concern that internet media have contributed to a fragmentation of audiences into isolated "issue publics" which operate as "digital enclaves" (de Sola Pool, 1984) of like-minded citizens reinforcing their own narrow range of views and prejudices rather than interacting to gain information and reach consensus.

Notwithstanding considerable criticism and scepticism, the concept of a public sphere has been enduring over more than 30 years since it was first proposed and, in recent revisions of the concept, Habermas (2006: 412) continues to posit the public sphere as "part of the bedrock of liberal democracies", particularly for deliberative democracy which he sees as preferable to liberal traditions that privilege the liberty of private citizens and make less demands for participation.

\section{Are spoofs, parodies and abuse part of the public sphere?}

Use of interactive internet media identified in studies such as the Australian Centre for Public Communication (2008) raises an important question about the nature of the public sphere today and what should be recognised as discourse in this important construction site of public opinion. In particular, are spoofs, parodies and, at the extreme, abuse part of the public sphere?

On the face of it, many uses of web 2.0 media identified do not seem to comply with normative notions of open, reasoned and rational debate among equals designed to contribute to deliberative democracy. Irrational and extreme viewpoints expressed, such as posts on YouTube in which "Look at me" or, worse, "Cu**" were typed repeatedly (YouTube comment, 2007), appear to signal a further failure of media to provide an effective public sphere, instead contributing to a 'descent' of the public sphere into entertainment and the worst aspects of popular culture such as extremism and obscene language. Other examples included 'mash ups' which remixed videos such as John Howard's climate change speech to make him look and sound ridiculous.

An alternative view is that spoofs, parodies and even abuse are a legitimate part of the public sphere, allowing people to express their views in a language and form that they choose, rather than forcing them to comply with what could be considered to be a lingering liberal bourgeois concept of political discourse. Jenkins (2006: 227) cites research by 
Buckingham (2000) which found that children and youth "find the language of politics unfamiliar and uninvolving compared with the immediacy offered by popular entertainment". Van Zoonen (1998a: 196-7) proposes that the popularising of political communication should be seen as an attempt to restore the relation between politicians and voters - although it should be noted that this supportive argument does not extend to obscene language or abuse such as racial vilification.

Evidence of spoofs, parodies and other comedic and entertaining treatments of political events and issues being part of political discourse can be found throughout history. Street (2001: 63) cites "the classic period for satire” including political satire in England between 1600 and 1800 led by writers such as Pope and Swift and the caricaturist James Gillray. The working class of $18^{\text {th }}$ century England challenged their masters in song and poetry rather than in newspapers or political forums to which they had little if any access or, if they did, little inclination to use (Thompson, 1968). Scott (1990) talks of how the poor and downtrodden have always inscribed their views within their culture such as Irish music not in the culture of traditional politics. More recently, Street (2001: 61) instances punk and rap of the 1980s and 1990s as sites of political discourse for youth, the disenfranchised and those disengaged from the traditional public sphere.

Traditional media genre also have utilised political spoofs and parodies, although abuse, defamatory comments and obscene content have been limited due to strict regulations. In Britain, the Left-wing New Statesman and the humour and satire journal Punch which popularised media cartoons regularly lampooned politicians and the Establishment (Street 2001: 66-7). While Punch was suitable for reading in English drawing rooms, Private Eye was a more strident critic of public figures and generated considerable ire among the Establishment because of its editorial policy of printing controversial and even defamatory articles. In Australia, Oz magazine founded in 1963 as a self-declared magazine of dissent before moving to London in 1967 published spoof articles and satirised politicians as well as publishing polemic on a range of issues. The publishers of $\mathrm{Oz}$ were charged with obscenity on two occasions, once in Australia and once in the UK, indicating that its content was well outside the traditional mediated public sphere (Fountain, 1988; Green 1999). Even a cursory analysis reveals that some of the cartoons and comments from these publications are not so different from the Photoshop-edited visuals and comments on YouTube during the Australian federal election.

Television programs such as Yes Minister, Spin City and spoof current programs are further examples of political comment being made through entertainment, satire, parodies and even ridicule. However, many of these media productions, and particularly web 2.0 content produced by individuals in other than journalistic format, fall outside Habermas' description of the public sphere. Habermas (2006: 416) acknowledges that "mediated political communication is carried on by an elite". It is dominated by, and often confined to, politicians (including their political parties), journalists, lobbyists, advocates who represent special interest groups, intellectuals, and moral entrepreneurs such as members of the clergy, the legal profession, environmentalists and so on (Habermas 2006: 416).

Habermas's own recent analysis leads us to the inevitable finding that the overwhelming majority of citizens in democratic societies are denied access to the public sphere. Yet, paradoxically, Habermas calls for a deliberative model of democracy requiring wide participation in the process of public opinion construction. He says: "the deliberative model expects the political public sphere to ensure the formation of a plurality of considered public opinions” (Habermas 2006: 416). 
This paradox can only be resolved in one of two ways. Either we abandon the pursuit of a deliberative model of democracy and settle for a liberal representative model in which a relatively small number of people are entrusted with and allowed to conduct politics on behalf of the populace, or we widen the notion of what is considered admissible and legitimate in terms of participation in the public sphere.

Street (2001: 61) says the boundary between conventional politics and popular culture has become "ever more porous" and it can be argued that, far from being a deterioration of the public sphere, web 2.0 media with their more open access and more user-friendly interface, format and language offer the potential for its reinvigoration. Or perhaps the public sphere as envisioned has never existed except in our imaginations and only now can it be realised? Van Zoonen (1998b: 49-50) suggests that the reconnection of politicians with popular culture is necessary for "constructing the politician as a human being with her or his individual peculiarities, rather than as the representative of particular policies or ideologies". This is part of a wider shift in politics from loyal party bases to individualism. Street (2001: 195) discusses how "the old ties of party and class loyalty which informed voters and voting have eroded". At the same time, newspaper readership and television viewing are declining, especially among young citizens (Australian Communications and Media Authority, 2007; Roy Morgan, 2007). Voters need to find new frameworks and environments in which to gain political information and discuss political issues.

Feminist scholarship has alerted us to the dangers of dominant paradigms prescribing language and shaping institutions, and increased recognition of differences in how individuals and groups speak based on gender, ethnicity, culture and other factors (Butler, 1991; Kristeva, 1980, 1981). A broader and more inclusive definition of the public sphere seems necessary to accept a wider range of communication that expresses individuals' and groups' views on political issues. Is a scream any less authentic and any less evocative than a rational statement? Whether one is reviewing the art of Munch (1893) or considering the metaphorical scream of cyber-graffitists, a viewpoint is being expressed and when it relates to matters political should it not be recognised as a vital and dynamic part of the public sphere?

\section{Is the digital public sphere accessible? The digital divide revisited}

A second key question which requires ongoing review is whether the 'digital divide' (Novak and Hoffman, 1998) between those with access to internet media and those with limited or no access is closing or whether it remains an obstacle to an effective public sphere. It is one thing to argue that these new media genre can potentially invigorate the public sphere and re-establish lost links between political processes and citizens, but if a significant digital divide remains in place, this potentiality cannot be realised and the benefits of internet media will be limited or denied to many.

There are three significant changes that are affecting of the digital divide as it exists in 2008. First, in terms of access to computers and the internet, the digital divide is rapidly closing in a number of societies. In the US and Europe, between 60 and 70 per cent of the population are now online - almost 200 million people in the US alone (Grossberg, et al., 2006: 453). An Australian Communications and Media Authority (2007) report on use of media by Australian families released in December 2007 reported that 98 per cent of Australian homes now have a computer (ahead of DVD players at 97 per cent) and 91 per cent have internet access, with 76 per cent having broadband. Less technologically developed societies including those on the vast continents of Asia, Africa and South 
America have much greater disparities between the 'haves' and 'have nots', but even here the digital divide is narrowing. Between 2000 and 2004 the number of internet users increased by 123 per cent in Africa, by 140 per cent in Latin America, and by 174 per cent in the Middle East (Grossberg, et al., 2006: 453). Notwithstanding, we need to be mindful that a digital divide in terms of access to computers and the internet remains in many countries and in disadvantaged sectors of developed societies such as Aboriginal people in Australia and the poor. As all media increasingly become digital, and digitally-enhanced democracy expands, governments wishing to have informed citizens and citizen engagement will need to consider initiatives to facilitate access for disadvantaged groups.

Second, production of content has been made substantially easier and less expensive with new media technologies. Not only are professional cameras and editing suites no longer required, but even computer programming such as HTML is not needed to produce videos or publish blogs. Third, distribution to large audiences with little or no cost has been made possible by web 2.0 internet applications such as MySpace, Facebook and YouTube.

But another dimension of the digital divide is potentially a greater site of conflict and tension than technological barriers. This dimension of the digital divide relates to practice and has three elements: technical (in terms of skills), social and cultural. These aspects of the gap between the public sphere and citizens lead to the third key question that this paper addresses.

\section{Can and will citizens effectively use a digital public sphere?}

Arguing for a broadening of the boundaries of the public sphere to include interactive web 2.0 media and for continuing expansion of access to internet media and communication tools only go so far in establishing a reinvigorated public sphere. In the final analysis, operationalisation of the public sphere depends on the ability, interest, willingness and propensity of citizens to access and participate in the public sphere in ways that promote citizenship and contribute to participatory democracy. While there is considerable enthusiasm for the potential offered by internet media, along with reservations and concerns, there are questions over its use for civic and political engagement at an individual level.

The first and most obvious barrier to expanded use of internet media is lack of digital literacy. Digital literacy has yet to spread throughout societies. Schools and universities are transforming curricula to include digital literacy enhancement, but it may be a generation before societies as a whole feel comfortable with digital internet media as noted by Lévy (1997). It is important to note that digital literacy is more than technical skills to use computers and the internet; it must be considered to include users feeling comfortable with internet media rather than fearful or intimidated. This requires knowing the associated language, protocols and customs such as the non-linear structure of hypertext and the specific mores and rules of particular online environments. Henry Jenkins (2006: 208) says "digital democracy will be decentralised, unevenly dispersed, profoundly contradictory, and slow to emerge”.

A further interesting perspective is provided in recent analysis by Xenos and Moy (2007: 705-08) who propose that citizens come to internet media via one of two approaches: an instrumental approach which involves a rational purposeful search for information and knowledge, or a psychological approach in which users' levels of interest, attitudes, social context and cultural background influence what they do with these media. When a 
psychological approach is orientated towards recreational use or social networking, users are unlikely to become active participants in the political public sphere. Research by Shah, et al. (2001) and Prior (2005) found that the instrumental approach is more associated with accumulation of information and knowledge and increases social capital, while the reverse is true for those orientated towards socio-recreational use. This concern about a substantial politically disengaged segment of online communities is given weight by Neuman (1991: 54) who describes "the psychology of the mass audience" as "semi-attentive" and “entertainment-orientated”.

This thinking points to a situation in which those already politically motivated and informed benefit from new forms of engagement, while others remain disengaged (Xenos and Moy, 2007: 708). However, the question of whether spoofs, parodies and other types of informal communication in internet media are to be regarded as recreation and entertainment, or whether they are valid expressions of viewpoints relevant to the public sphere, becomes all the more salient. A broader definition of what constitutes participation in the public sphere would see functional and recreational uses of the internet less demarcated and possibly show an increase in civic engagement.

Another approach that questions and critiques the normative view of deliberative and participatory democracy is Schudson's concept of the monitorial citizen (Schudson, 2003:

55). He proposes that in an age of information overload it is no longer possible for people to be informed citizens equipped for deliberative participation as espoused by Habermas. Instead, Schudson says "monitorial citizens tend to be defensive rather than pro-active", they engage in environmental surveillance more than information gathering, and act only when an issue reaches a certain threshold of interest or tolerance. The "monitorial citizen" approaches the public sphere differently to the deliberative and contemplative citizen envisioned by Habermas, preferring to observe rather than participate in most instances. Internet sites provide a greatly expanded number of vantage points to observe and monitor and, from this perspective, are useful tools for citizens allowing them to not only engage but to monitor more effectively than before.

Schudson's concept of the monitorial citizen has support in analyses of what constitutes interaction and participation. While many scholars see what McMillan (2002: 172) calls "user to system interactivity" as not constituting interaction in any human or political sense of the term, she further identifies "user to documents interactivity" which she says can involve "parasocial interaction" (McMillan, 2002: 169) and also "user to user interaction" (McMillan, 2002: 166) occurring on the internet, particularly in web 2.0 applications. While the latter clearly involves what most would consider engagement, the accessing of information in documents and observing (what is called 'lurking' on the internet) also is a form of engagement and participation. It can be argued that citizens become informed by silently observing and that their silence in interactive communication environments such as web 2.0 is a form of participation (e.g. indicating consent or acceptance). This argument gains further weight in studies that problematise the concept of audiences, typically seen as passive receptacles for messages, but reconceptualised in cultural studies as participants actively interpreting information and texts (Fenton, 2007: 17-19) and sometimes appropriating texts for purposes other than those intended by the producers. 


\section{Conclusions}

While some may feel this is a 'watering down' of the concept of participation in the public sphere, it does offer another perspective. It recognises that not all citizens want to actively engage in political discourse and that those who do want to engage at different levels and in different ways. In this view, the vastly expanded opportunities and levels of interaction offered by web 2.0 internet media are important and enable increased participation.

While Australian Centre for Public Communication (2008) research during the 2007 Australian federal election did not show a revolutionary change in the functioning of the public sphere, it did reveal evolutionary change - particularly in increased access to communication channels for interest and activist groups, many of which previously had little access to media, and in providing a public platform for individual citizens who traditionally have had little opportunity to express their views to a large special interest, national or even global audience. The research found that the latter forum included discussion and communication artefacts that would not be considered part of the public sphere as envisaged by Habermas and in revisionist conceptualisations. As McNair (2006, cited in Flew 2008: 165) notes, the internet is a "more crowded, noisy, chaotic, competitive, and rancorous communications space than was envisaged for the modernist public sphere”. But perhaps the Greek angora-inspired public sphere is a myth and the "noisy, chaotic, competitive, and rancorous communications space" of web 2.0 media is an actualisation of the public sphere.

A concluding observation is that it is probably time to drop the terms 'mainstream media', 'new media' and 'social media' which are widely used. While Facebook was launched publicly only in 2004 and YouTube started even more recently in 2005, the term Weblog shortened to 'blog' was coined in 1997 (Wortham, 2007) and blogs began appearing regularly in 1998-99 (Nightingale and Dwyer, 2007: 109). Google celebrated its $10^{\text {th }}$ anniversary in 2008 and MySpace will be decade old in 2009. As Terry Flew (2008: 2) notes in New Media: An Introduction, "digital media technologies are now so pervasive in our work, our home lives, and the myriad everyday interactions we have with each other as well as with social institutions, that they are ceasing to be 'new' in any meaningful sense of the term". So-called social media such as MySpace and YouTube are being used increasingly in business and for political communication as well as social networking, as this research and other studies have found.

\section{References}

A ringing endorsement, 2007, The Australian, 25 October 2007, p. 32.

Australian Centre for Public Communication, 2008, 'E-Electioneering: Use of New Media in the 2007 Australian Federal Election', research report, University of Technology Sydney, January.

Australian Communications and Media Authority, 2007, 'Media and Communications in Australian Families 2007: Report of the Media and Society Research Project', Canberra, January.

Bentivegna, S, 2002, 'Politics and New Media', in (eds) L. Lievrouw and S. Livingstone, The Handbook of New Media, Sage, Thousand Oaks, CA, pp. 50-61.

Buckingham, D, 2000, The Making of Citizens: Young People, News and Politics, Routledge, London.

Butler, J, 1999, Gender Trouble: Feminism and the Subversion of Identity, Routledge New York. Corner, J, 2007, 'Media, Power and Political Culture', in (ed) E. Devereaux, Media studies: Key issues and Debates, Sage, London, pp. 211-30.

Costello, P, 2007, Peter's Blurb, blog, http://www.myspace.com/petercostello

Curran, J, 2002, Media and Power, Routledge London. 
Fallows, J, 2000, 'Internet Illusions’, New York Times Book Review, 16 November, pp. 28-31. Flew, T, 2005, New Media: An Introduction, $2^{\text {rd }}$ edn, Oxford University Press, South Melbourne. Flew, T, 2008, New Media: An Introduction, $3^{\text {rd }}$ edn, Oxford University Press, South Melbourne. Foucault, M, 1980, 'The History of Sexuality: An Interview', Oxford Literary Review, 4, p. 1.

Foucault, M, 1998, The Will to Knowledge: The History of Sexuality, Vol 1, The Care of the Self (R. Hurley, trans), Penguin, London.

Fountain, N 1988, Underground: The London Alternative Press 1966-74, Commedia/Routledge, London.

Garnham, N, 1992, 'The Media and the Public Sphere', in (ed) C. Calhoun, Habermas and the Public Sphere, MIT Press Cambridge, MA.

Green, J, 1999, All Dressed Up: The Sixties and the Counterculture, London, Pmlico.

Gitlin, T, 1998, 'Public Spheres or Public Sphericles?' in (eds) T. Liebes and J. Curran, Media, Ritual and Identity, Routledge, New York.

Goode, L, 2005, Jurgen Habermas: Democracy and the Public Sphere, Pluto Press, London.

Grossberg, L, Wartella, E, Whitney, D, and Wise, M, 2006, Media Making: Mass Media in a Popular Culture, Sage Publications, Thousand Oaks, CA.

Habermas, J, 1989, The Structural Transformation of the Public Sphere, Polity, Cambridge, UK. (Original work published 1962)

Habermas, J, 2006, 'Political Communication in Media Society: Does Democracy Still Enjoy an Epistemic Dimension? The impact of Normative Theory on Empirical Research', Communication Theory, vol. 16, no 4, November, pp. 411-26.

Hill, K, and Hughes, J, 1998, Cyperpolitics: Citizen Activism in the Age of the Internet, Rowman and Littlefield, New York.

Hoffman, D, and Novak, T, 1998, 'Information Access: Bridging the Racial Divide on the Internet', Science, no. 280 (5362), pp. 390-1.

Howley, K, 2007, 'Community Media and the Public Sphere', in (ed) E. Devereaux, Media Studies: Key Issues and Debates, Sage Publications, London, pp. 342-60.

Jenkins, H, 2006, Convergence Culture: Where Old and New Media Collide, New York University Press.

Jones, S (ed.), 1995, Cybersociety: Computer-Mediated Communication and Community, Sage, Thousand Oaks, CA.

Jones, S (ed.), 1998, Cybersociety 2.0: Revisiting Computer-Mediated Communication and Community, Sage, Thousand Oaks, CA.

Katz, E, Blumler, J, and Gurevitch, M, 1973, 'Uses and Gratifications Research', Public Opinion Quarterly, no. 37, pp. 509-23.

Katz, E, Blumler, J, and Gurevitch, M, 1974, 'Utilization of Mass Communication by the Individual, in (eds) J. Blumler and E. Katz, The Uses of Mass Communications: Current Perspectives on Gratifications Research, Sage, Beverly Hills, CA, pp. 19-32.

Kristeva, J, 1980, Desire in Language: A Semiotic Approach to Literature and Art, Columbia University Press, New York.

Kristeva, J, 1981, 'Woman’s Time’ (A. Jardine, trans), Signs, vol. 7, no. 1, reprinted.

Lévy, P, 1997, Collective Intelligence: Mankind's Emerging World of Cyberspace, Perseus Books, Cambridge, MA.

Livingstone, S, 1999, 'New Media, New Audiences', New Media \& Society, vol. 1, no. 1, pp. 59 66.

Lievrouw, L, and Livingstone, S (eds), 2002, The Handbook of New Media, Sage, London.

Markle Foundation, 1997, The State of 'Electronically Enhanced Democracy: A Survey of the Internet, October.

McChesney, R, 1996, 'The Internet and US Communication Policy-Making in Historical and Critical Perspective', Journal of Communication, no. 46, pp. 98-124.

McChesney, R, 2000, Rich Media, Poor Democracy: Communication Politics in Dubious Times rev. edn, New Press, New York.

Media Monitors, 2008, 'E-Election Media Analysis Report', January, Sydney.

Munch, E, 1893, The Scream, oil paining on cardboard, National Gallery, Oslo, Norway.

Neuman, W, 1991, The Future of the Mass Audience, Cambridge University Press, Cambridge, UK. 
Nightingale, V, and Dwyer, T (eds), 2007, New Media Worlds: Challenges for Convergence, Oxford University Press, South Melbourne.

Novak, T, and Hoffman, D, 1998, 'Bridging the Digital Divide: The Impact of Race on Computer Access and Internet Use', Project 2000, Vanderbilt University, http://www.vanderbilt.edu/News/register/April20_98/vr13.html

O'Reilly, T, 2005, 'What is web 2.0: Design patterns and business models for the next generation of software', O'Reilly blog post, 30 September, http://www.oreillynet.com/pub/a/oreilly/tim/news/2005/09/30/what-is-web-20.html

Poll puts it all online, 2007, The Daily Telegraph, Short Circuits column, 19 September, p. 6.

Pool, I de Sola, 1983, Technologies of Freedom, Belknap, Cambridge, MA.

Poster, M, 1997, 'Cyberdemocracy: Internet and the Public Sphere' in (ed.) D. Porter, Internet Culture, Routledge, New York and London.

Poster, M, 2006, 'Culture and Media: Introduction' in (eds) L. Lievrouw and S. Livingstone, The Handbook of New Media, Sage, London, pp. 479-84.

Prior, M, 2005, 'News vs. Entertainment: How Increasing Media Choice Widens Gaps in Political Knowledge and Turnout', American Journal of Political Science, no. 49, pp. 577-92.

Putnam, R, 1995, Bowling Alone: America's Declining Social Capital, Journal of Democracy, vol. 61 , no. 1 , pp. $65-78$.

Putnam, R, 2000, Bowling Alone: The Collapse and Revival of America Community, Simon \& Schuster, New York.

Rheingold, H, 1993, The Virtual Community: Homesteading on the Electronic Frontier, AddisonWesley, Reading, MA.

Roy Morgan Research, 2007, Newspaper readership survey data for the period 1 July 2006 to 30 June 2007.

Schlotzer, A, 2007, Alex's Rants, Raves and Thoughts, http://alexschlotzer.blogspot.com/2007/12/ive-thoroughly-enjoyed-scouring-youtube.html

Schneider, S, 1996, 'A Case Study of Abortion: Conversation on the Internet', Social Science Computer Review, vol. 14, no. 4, pp. 373-93.

Schneider, S, 1997, 'Expanding the Public Sphere Through Computer-Mediated Communication: Political Discussion about Abortion in a Usenet Newsgroup', PhD dissertation, Massachusetts Institute of Technolgoy, Cambridge, MA. (Available online: http://www.sunyit.edu/ steve/)

Schudson, M, 2003, 'Click Here for Democracy: A History and Critique of an Information-Based Model of Citizenship', in (eds) H. Jenkins and D. Thorburn, Democracy and New Media, MIT Press, Cambridge, MA.

Severin, W, and Tankard, J, 2001, Communication Theories: Origins, Methods, and Uses in the Mass Media, Addison Wesley Longman, New York.

Shah, D, Kwak, N, and Holbert, R, 2001, 'Connecting and Disconnecting with Civic Life: Patterns of Internet Use and the Production of Social Capital', Political Communication, no. 18, pp. $141-62$.

Shapiro, A, and Leone R, 1999, The Control Revolution: How the Internet is Putting Individuals in Charge and Changing the World We Know, Public Affairs Century Foundation, New York.

Sparks, G, 2006, Media Effects Research: A Basic Overview, $2^{\text {nd }}$ edn, Thomson Wadsworth, Belmont, CA.

Street, J, 2001, Mass Media, Politics and Democracy, Palgrave, Basingstoke, Hampshire, UK.

The You-Tube Election, 2007, Sydney Morning Herald, 14 July, p. 23.

Van Zoonen, L, 1998a, 'A Day at the Zoo: Political Communication, Pigs and Popular Culture', Media, Culture and Society, vol. 20, no. 2, pp. 183-200.

Van Zoonen, L, 1998b, “"Finally I have my mother back": Politicians and their families in popular culture', Harvard International Journal of Press/Politics, vol, 2, no. 1, pp. 48 -64.

Warner, M, 2002, Publics and Counterpublics, Zone Books, USA.

Wellman, B, 2000, 'Physical place and cyberspace: The rise of networked individualism, International Journal of Urban and Regional Research, December.

Wortham, J, 2007, 'After 10 years of blogs: The future's brighter than ever', Wired, 17 December, http://www.wired.com/entertainment/theweb/news/2007/12/blog_anniversary

Xenos, M, and Moy, P, 2007, 'Direct and Differential Effects of the Internet on Political and Civic Engagement', Journal of Communication, vol. 57, no. 4, December, pp. 704-18. 
Young Voters Caught Hook, Line and Sinker, 2007, Sydney Morning Herald, World, 23 - 24 June, p. 21.

YouTube comment, 2007, 'BeingAssRapedIsFun', comment on John Howard posted on YouTube, 4 months ago, http://www.youtube.com/comment_servlet?all_comments\&v=e5jtiJPlv4Y

$1 \quad$ Web 2.0, a term reportedly coined by Tim O’Reilly in collaboration with MediaLive International in 2004 refers to a second generation of internet applications and utilities that allow interactivity such as comment posting, feedback, and collaborative production. See O’Reilly (2005).

2 'Surfing' refers to pre-search engine ad hoc navigation of the internet which was often time-consuming and sometimes fruitless. Intelligent search engines such as Google have made 'surfing' largely redundant.

* Jim Macnamara PhD, MA, FPRIA, FAMI, CPM, FAMEC is Professor of Public Communication at the University of Technology Sydney and Director of the Australian Centre of Public Communication, positions he took up in 2007 after a 30-year professional career spanning journalism, public relations, advertising, and media research. He is the author of 12 books including 'The $21^{\text {st }}$ Century Media (R)evolution: Emergent Communication Practices' published by Peter Lang, New York in 2010. 